\title{
Recent challenges of the European integration: an introduction
}

\section{Cândida Ferreira ${ }^{1}$ - Camélia Turcu ${ }^{2}$}

Published online: 15 March 2019

C) Springer-Verlag GmbH Germany, part of Springer Nature 2019

This special issue entitled "Recent Challenges of the European Integration" includes four articles which provide a recent analysis of the main channels of international economic integration (trade in goods and capital flows) as well as a thorough study of economic and productivity growth dynamics in a globalized world. These articles develop either a comparative research perspective by analyzing together several European Union (EU) countries or an in-depth analysis of an EU member state (i.e. Portugal).

The general framework put forward in this special issue, both in theoretical and empirical terms, provides an overview of the economic interactions between economies in a globalized world and more specifically, in the context of the European construction. A certain number of issues are raised: Are trade agreements enhancing exports and trade margins? How does foreign direct investment (FDI) affect trade? What are the linkages between structural changes, human capital and productivity growth?

The selected papers can be grouped as follows. A first group of papers analyzes trade agreements and foreign investment in Europe. Firstly, the impact of Regional Trade Agreements (RTAs) on European exports is addressed (Zuzanna Studnicka, Wouter Thierie and Jan Van Hove). Then, the complementarities between trade and foreign direct investment are analyzed in the context of the European integration of Central and Eastern European countries (CEECs) (Claudiu Albulescu and Daniel Goyeau). A second category of articles deals with specific aspects related to international trade, countries' production structure and productivity growth in several European countries. Marta Simões, Adelaide Duarte and João Sousa Andrade show that productivity growth can be linked not only to trade, but also to human capital and structural change,

Cândida Ferreira

candidaf@iseg.ulisboa.pt

Camélia Turcu

camelia.turcu@univ-orleans.fr

1 Department of Economics, Lisboa School of Economics and Management, University of Lisbon (ISEG, UL), Rua Miguel Lupi, 20, 1249-078 Lisbon, Portugal

2 LEO CNRS FRE 2014, University of Orleans and INFER, Rue de Blois, BP 26739, 45067 Orléans, France 
especially in a small economy such as Portugal. The issue of structural change, regional competitiveness and productivity growth is addressed by Ansgar Belke, Nicos Christodoulakis and Daniel Gros when comparing a Greek and German region.

Zuzanna Studnicka, Wouter Thierie and Jan Van Hove investigate the effects of European RTAs on European export patterns and show the existence of important heterogeneity across EU members. They use panel data and augment, in a first step, the traditional gravity model with a dummy variable capturing the presence of an RTA between EU and non-EU members. Their results underline that only the extensive margin is positively affected by trade agreements. The authors also examine whether the impact of RTAs on total exports and the margins of trade is homogenous or heterogeneous across EU members. They find that the presence of a European RTA with EU non-members positively impacts total exports mainly in the Central and Eastern European Countries (CEECs) and EU peripheral countries. Further on, the authors take account of different trade-related aspects included in trade arrangements. They show that although the impact of an RTA as a whole does not significantly affect total exports, some of the underlying trade issues included in an RTA have positive and significant effects. Again, the extensive margins are the ones that are mainly affected. This implies that the inclusion of specific trade subjects in an RTA can encourage EU members to export a larger set of goods. Finally, a composite index measuring the scope and intensity of trade integration in relation to the European trade agreements is computed. This index does not have significant impact, neither on total exports, nor on the margins of trade. This suggests that the EU does not export more to trading partners it concluded deeper trade agreements with. However, a closer look to the impact on individual EU member states suggests increasing heterogeneity among EU exporters. Claudiu Albulescu and Daniel Goyeau examine trade integration among the Vysegrade group of countries. These are a group of Central and Eastern European Countries (CEECs) within the EU, that includes the Czech Republic, Hungary, Poland and the Slovak Republic. The authors study the link between bilateral trade and foreign direct investment (FDI) in the case of the four CEECs over the period 2000-2013. To do this, they employ a panel gravitational model and consider the interactions that the four CEECS have among themselves but also with other EU member states. Different facets of the trade - FDI nexus are analyzed, using fixed effects and random effects models, as well as an instrumental variable estimator. The results suggest that outward FDI encourages CEECs trade integration, while inward FDI has no significant effect on bilateral trade. Hence, a complementarity effect between trade and outward FDI is documented and this effect seems stronger if the CEECs historical trade partners are considered.

Marta Simões, Adelaide Duarte and João Sousa Andrade investigate the link between the services sector expansion, the human capital development and the aggregate productivity, in Portugal, over the period 1970-2006. The authors use VAR models to test two types of causality (i.e. Granger and instantaneous) and perform an impulse response analysis to test if the increasing tertiarization of the Portuguese economy is linked to human capital availability, on the one hand, and was an obstacle or an opportunity for country's aggregate productivity, on the other hand. The analysis is developed at an aggregate level but also at the sub-sectors level (i.e. 5 sub-sectors are considered) as the services sector is composed of heterogeneous activities in terms of their potential for productivity growth. The results suggest a bi-directional causality between services sub-sectors employment shares and aggregate productivity. Human 
capital does not play a significant role in explaining this outcome. The heterogeneity across sectors in also taken into consideration in the analysis. The authors show that community, social and personal services (i.e. health care and education activities) are key factors in human capital accumulation. Finance, insurance, real estate and business services are also supposed to increase productivity. Hence, the authors conclude that the development of modern progressive services sectors in Portugal can sustain aggregate productivity growth. Additionally, the results emphasize that specific traditional personal services sub-sectors should be strengthened in order to enhance human capital, a main driver of productivity growth.

Ansgar Belke, Nicos Christodoulakis and Daniel Gros analyze, in a comparative perspective, Germany and Greece. They study the structural characteristics of the Greek economy and workforce, with a specific focus on the Northern region of Greece, Thessaloniki. This region is compared to a German region, the Ruhr district - NRW. Against the background of the (at least partially) successful structural change in the Ruhrgebiet (Ruhr district), this paper investigates whether and to what extent the current problem countries in the euro zone, and their regions, as exemplified by Northern Greece here, can learn from the Ruhrgebiet when conducting structural reforms and managing structural change. The two regions analyzed (Northern Greece and Ruhrgebiet) are characterized by key similarities in the problems they face (for example, the low qualifications of the workforce) but there are also some differences between the regions: in particular the importance of industry and manufacturing. Industry and manufacturing was very important in the Ruhrgebiet, but it appears to be less so in Northern Greece. All in all, however, these regions are comparable: Northern Greece is one of the few remaining manufacturing centres in the country, and its role in the Greek economy is said to be similar to the one of the Ruhr district NRW within the German economy. Moreover, Northern Greece is the home of important energy resources, as it is also the case of Ruhr district - NRW. Lignite dominates power generation in Greece (as in Ruhrgebiet), but its contribution to the regional and local economy seems rather limited, both in the Ruhr district - NRW and in Northern Greece. In the Ruhrgebiet, the process of structural change seems to be almost complete, and it was a rather successful process (e.g. more than half of the workforce is now employed in the services sector -and service sector employment levels are still increasing). Hence, the purpose of this study is to see which lessons can be learned by Northern Greece, based on the Ruhr district - NRW experience, in terms of sectoral innovation.

Together all these papers represent an innovative contribution in international and European economics and suggest relevant policy implications. All four papers have been presented at workshops and conferences organized or supported by INFER (International Network For Economic Research).

Acknowledgements We are grateful to the journal International Economics and Economic Policy and in particular to the Managing Editor, Christian Richter, for the support provided during the preparation of this special issue. Many thanks also to David Duffy for his comments and suggestions.

Publisher's note Springer Nature remains neutral with regard to jurisdictional claims in published maps and institutional affiliations. 